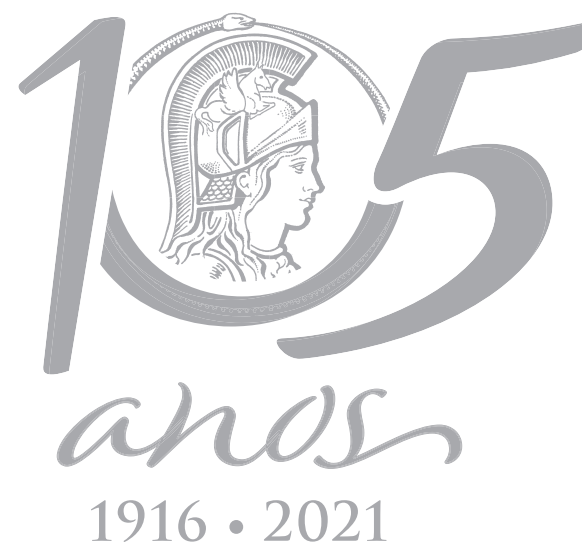

\title{
ECOSYSTEMS
}

\section{Malacofauna of lotic environments in the Northeast and Brazilian semiarid region: current knowledge and new records}

\author{
MANUELLA F. LEAL, LUIZ RICARDO L. SIMONE, EMERSON S. CASTRO, ORIANNA \\ DOS SANTOS, ANTÔNIA R.V. DA SILVA, KARINA K.S. DANTAS, JOÃO H. DE SOUSA, \\ EDSON L. DA SILVA, TAMARIS G. PINHEIRO \& ANA CAROLINA F. LACERDA
}

\begin{abstract}
Despite the great diversity, economic and environmental importance of limnic mollusks, the group is still little investigated in the Brazilian semiarid region, especially in the state of Piauí. Thus, this work aims to gather information on the diversity of limnic mollusks in the Brazilian Northeast and the semiarid region, including new records for the state of Piaui, northeastern Brazil. For this, collections in the urban perimeter of the Itaim and Guaribas Rivers, municipalities of Itainópolis, and Picos, respectively, between October 2017 and September 2019. Besides, a literature review was conducted on studies of malacofauna in the Northeast and the Brazilian semiarid region. A total of 11 species from the classes Gastropoda and Bivalvia were collected on the rivers of Piauí, being the first record of Uncancylus concentricus for the Northeast region. For lotic environments in the state of Piauí, Drepanotrema schubarti, Pomacea canaliculata, Pisidium dorbignyi and Stenophysa marmorata were registered for the first time. Then, it was possible to verify that the Northeast of Brazil has 71 species registered, of which 34 occur in the semiarid. The diversity of species surveyed and the first record of the occurrence of several of them for the semiarid region demonstrate the importance of expanding studies involving this group to other areas. The present study is the first to gather and increase the information available on the fauna of limnic mollusks for the Northeast and Brazilian semiarid regions. The information gathered here may contribute to future research and to the species conservation and the environments they occupy, especially considering the presence of non- native and vector species.
\end{abstract}

Key words: Bivalvia, exotic species, Gastropoda, intermediate host, Mollusca.

\section{INTRODUCTION}

Semiarid regions are characterized by having extreme climatic conditions caused by irregular rainfall regimes, with long periods of drought, taking the negative water balance (Silva et al. 2020a, Vidal-Abarca et al. 1992). It is estimated that around $4.8 \%$ of semiarid regions are degraded worldwide. Among the main causes of this problem are human activities linked to population pressure and exploitation of natural resources (Randklev et al. 2018, Manaye et al. 2019).

In Brazil, the semiarid region occupies an area of 1,128,697 km², covering 10 states, extending from Piauí to Minas Gerais, which is among the three largest in Latin America (Barbosa et al. 2012, Brasil 2017). This region is characterized by low rainfall, high evaporation rates, and temperature throughout the year, which cause cycles with irregular periods of drought and flood (Maltchick \& Florín 2002, 
Rocha et al. 2012, Silva et al. 2020a). This water regime contributes to the fact that most rivers have temporary regimes (Zanella 2014), remaining dry most of the year (Magalhães et al. 2016). In these rivers, it is common to observe the formation of temporary and semipermanent puddles during periods of severe droughts. Puddles become important refuges for the maintenance of local biodiversity (Maltchik \& Medeiros 2006, Hay et al. 2018) and the survival of the human population (Magalhães et al. 2016).

Freshwater ecosystems of the semiarid region are especially important as they bring together a diversity of under-explored biological groups, among them mollusks. Despite its great diversity and importance in freshwater ecosystems from the semiarid region, these animals are poorly studied. Studies on this group in Brazilian semiarid are still incipient and do not emphasize its importance to regional biodiversity (Abílio et al. 2006, 2007, Kotzian \& Amaral 2013, Silva et al. 2019, 2020b).

Considering the information gap on limnic mollusks in the Northeast and the Brazilian semiarid, mainly for the state of Piaui, in this work we gather the existing information about this group for these regions, including new records for two rivers in this state.

\section{MATERIALS AND METHODS}

\section{Bibliographic research}

A literature review was conducted on studies of malacofauna in the Northeast and the Brazilian semiarid region (including the state of Minas Gerais), (Supplementary Material - Table SI). The review included scientific articles and gray literature (theses, dissertations, and annals of events) published in English and Portuguese until 2020. The data were obtained from the Google Scholar, Web of Science, and Scopus databases, using the following keywords (combined or not): Limnic mollusks, Northeast, species list, and semiarid. Documents that did not mention the catalogue number in scientific collections and/ or how mollusks were identified, were excluded from the research.

The data analysis process considered information such as publication year (grouped in intervals to enhance visualization), taxa, state, environment, and type of research. The data were separated according to the environment of the sampling. The samples belonging to semiarid stricto sensu, including research developed in the state of Minas Gerais (a state that does not belong to the Brazilian Northeast region), coastal area, Baixada Maranhense and Zona da Mata and Amazon environment. This process follows the denomination used by the authors. The similarities in the species composition among the environment types were accessed through Jaccard's Index, using the Vegan package version 2.5-7 (Oksanen et al. 2020), on R v. 4.0.5 (R Core Team 2021).

\section{Field collection in Piauí}

The collections were carried out in the urban perimeter of the Itaim River, in the city of Itainópolis, and of the Guaribas River in the city of Picos, Southeast of Piaui, both belonging to the Parnaiba River basin. The Itaim River is $200 \mathrm{~km}$ long, covering six municipalities in the state and is one of the three main rivers in the Southeast of Piaui (Brasil 2005). The Guaribas River is $\sim 160 \mathrm{~km}$ long and is an important tributary of the Itaim River.

Although these two rivers are intermittent, like most rivers in the basin, during the dry season, at some points they have a perennial character, presenting a reduced volume of water, leading to a semi-lentic phase (Brasil 2005). Also, the Guaribas River still has a high level of pollution from the deposition of solid waste on 
the bed and its margins, and the discharge of untreated domestic effluents (Santos et al. 2017).

Mollusks were collected monthly between October 2017 and September 2019, at five sampling stations established in each river. Collections used sieves of $21 \mathrm{~cm}$ in diameter, attached to a wooden rod of $1.5 \mathrm{~m}$ in length. The mollusks were stored in plastic containers, along with the substrate and local water. All material was transported to the Laboratório de Parasitologia, Ecologia e Doenças Negligenciadas (LAPEDONE) of the Instituto Federal do Piaui for the identification of individuals. All procedures for collecting and transporting the animals were carried out under the authorization of the Instituto Chico Mendes de Conservação da Biodiversidade (ICMBio), through the Sistema de Autorização e Informação em Biodiversidade (SISBIO), license number 60423-5.

The animals were preserved in $98 \%$ ethanol and identified according to the classification proposed by Paraense $(1975,2003)$ and Simone (2006). Part of the collected material was deposited at the Museu de Zoologia da Universidade de São Paulo (MZUSP) and in the Coleção Malacológica do Instituto Oswaldo Cruz (CMIOC) (Table I).

\section{RESULTS}

\section{Bibliographic survey}

A total of 97 studies was recorded considering the inclusion criteria used in this research. The oldest publication dates back to 1983 (Figure 1a), 10 of these studies included more than one state, highlighting Pernambuco with most research ( $n=28 ; 21,5 \%)$, followed by Paraíba ( $n=$ 22; 16,9\%) (Figure 1b).

Regarding the environment in which these works were carried out, 12 studies included more than one environment and two without identification. The semiarid environment stood out for the higher number of articles ( $n=$ 65), followed by coastal areas $(n=36)$ (Figure 1c). Baixada Maranhense, Zona da Mata, and Amazon environment represent little more than $5 \%$ of the total analyzed studies (Figure 1c). Concerning the research focus, most of them are focused on parasite vectors $(n=36)$, inventories $(n=23)$ and non-native species $(n=23)$. Studies with macroinvertebrates and ecology represent, together, about $15 \%$ of the studies (Figure $1 d$ ).

Most of the 65 studies found about the semiarid were carried out during the last decade (Figure 2a). As for the research types on the semiarid, stands out the inventories and non-native species, with 18 studies each and 16 related to parasite vector (Figure $2 b$ ). Paraíba and Pernambuco states have the largest number of inventories of limnic mollusks in the Brazilian semiarid (Figure 2c). In the semiarid region of Piauí, only one study has been carried out so far (Figure 2c).

The bibliographic survey revealed 70 recorded species distributed in 15 families of Gastropoda and Bivalvia classes. The richest environment is semiarid with 31 species, followed by coastal areas $(n=16)$, Baixada Maranhense ( $n=14)$, Zona da mata $(n=9)$, and Amazon environment $(n=8)$ (Figure 3a). The Jaccard index for species composition revealed that Zona da Mata and the Amazon environment have $80 \%$ similarity (first cluster). Baixada Maranhense has $60 \%$ similarity to the cluster formed by the semiarid and coastal (second cluster). The former and the latter are $50 \%$ similar to each other (Figure $3 \mathrm{~b}$ ). Ten species (14\%) were exclusive to semiarid and only one (1.4\%) is exclusive to the coastal area (Pomacea bridgesii (Reeve, 1856)), Zona da Mata (Tarebia granifera (Lamarck, 1816)) and Amazon environment (Antillorbis nordestensis (Lucena, 1954)) each. Baixada Maranhense presented no 
Table I. List of mollusks collected in the Itaim ( $\left.7^{\circ} 26^{\prime} 42.9^{\prime \prime} \mathrm{S} 41^{\circ} 28^{\prime} 41.1^{\prime \prime} \mathrm{W}\right)$ and Guaribas ( $\left.7^{\circ} 04^{\prime} 39.9^{\prime \prime} \mathrm{S} 41^{\circ} 27^{\prime} 58.1^{\prime \prime} \mathrm{W}\right)$ Rivers, Piauí, from October 2017 to September 2019. MZUSP: Museu de Zoologia da Universidade de São Paulo; CMIOC: Coleção Malacológica do Instituto Oswaldo Cruz.

\begin{tabular}{|c|c|c|c|c|c|c|c|}
\hline Class & Family & Species & River & City & $\begin{array}{l}\text { Absolut } \\
\text { frequency }\end{array}$ & $\begin{array}{l}\text { Relative } \\
\text { frequency } \\
\text { (\%) }\end{array}$ & Voucher number \\
\hline \multirow{12}{*}{ Gastropoda } & \multirow{7}{*}{ Planorbidae } & \multirow{2}{*}{$\begin{array}{l}\text { Biomphalaria } \\
\text { straminea } \\
\text { (Dunker, 1848) }\end{array}$} & Itaim & Itainópolis & \multirow{2}{*}{3,800} & \multirow{2}{*}{15.10} & MZUSP 14.6745 \\
\hline & & & Guaribas & Picos & & & MZUSP 14.6740 \\
\hline & & $\begin{array}{c}\text { Drepanotrema } \\
\text { lucidum } \\
\text { (L. Pfeiffer, 1839) }\end{array}$ & Guaribas & Picos & 126 & 0.50 & CMIOC 11.595 \\
\hline & & $\begin{array}{c}\text { Drepanotrema } \\
\text { cimex } \\
\text { (Moricand, 1839) }\end{array}$ & Guaribas & Picos & 106 & 0.40 & MZUSP 14.6739 \\
\hline & & $\begin{array}{c}\text { Drepanotrema } \\
\text { depressissimum } \\
\text { (Moricand, 1839) }\end{array}$ & Guaribas & Picos & 749 & 2.98 & MZUSP 15.1482 \\
\hline & & $\begin{array}{l}\text { Drepanotrema } \\
\text { schubarti } \\
\text { (Haas, 1938) }\end{array}$ & Guaribas & Picos & 1,233 & 4.90 & MZUSP 15.1485 \\
\hline & & $\begin{array}{c}\text { Uncancylus } \\
\text { concentricus } \\
\text { (d'Orbigny, 1835) }\end{array}$ & Guaribas & Picos & 2 & 0.01 & MZUSP 14.6737 \\
\hline & \multirow{2}{*}{ Thiaridae } & \multirow{2}{*}{$\begin{array}{c}\text { Melanoides } \\
\text { tuberculatus } \\
\text { (O. F. Müller, 1774) }\end{array}$} & Itaim & Itainópolis & \multirow{2}{*}{18,234} & \multirow{2}{*}{72.45} & MZUSP 14.6742 \\
\hline & & & Guaribas & Picos & & & MZUSP 14.6738 \\
\hline & \multirow{2}{*}{ Ampullariidae } & \multirow{2}{*}{$\begin{array}{c}\text { Pomacea } \\
\text { canaliculata } \\
\text { (Lamarck, 1822) }\end{array}$} & Itaim & Itainópolis & \multirow{2}{*}{476} & \multirow{2}{*}{1.89} & MZUSP 14.6720 \\
\hline & & & Guaribas & Picos & & & MZUSP 14.6734 \\
\hline & Physidae & $\begin{array}{l}\text { Stenophysa } \\
\text { marmorata } \\
\text { (Guilding, 1828) }\end{array}$ & Guaribas & Picos & 196 & 0.78 & MZUSP 14.6747 \\
\hline \multirow{2}{*}{ Bivalvia } & Sphaeriidae & $\begin{array}{c}\text { Pisidium } \\
\text { dorbignyi } \\
\text { Clessin, } 1879\end{array}$ & Itaim & Itainópolis & 243 & 0.97 & MZUSP 14.6743 \\
\hline & Cyrenidae & $\begin{array}{c}\text { Corbicula } \\
\text { fluminea } \\
\text { (O.F. Müller, 1774) }\end{array}$ & Itaim & Itainópolis & 3 & 0.01 & MZUSP 15.1417 \\
\hline
\end{tabular}


exclusive species. A total of 35 species was not assigned to any environment (Table - SI).

Concerning the diversity of species by state, Pernambuco again stands out $(n=46)$, followed by Bahia ( $n=38$ ). Maranhão, Ceará, Paraíba, Rio Grande do Norte and Sergipe have a mean of 15 species. Piauí and Alagoas present a lower number of registered species (Figure 3c). Regarding the number of studies by mollusk species, $43(61.4 \%)$ species were cited in only one article, 14 were present in two to four (20\%) studies and 13 (18.6\%) appear in more than five publications.

Among the gastropods, Melanoides tuberculatus (O. F. Müller, 1774) (Thiaridae) reached the higher numbers of records ( $n=49$ ), followed by Biomphalaria straminea (Dunker, 1848) ( $n=43$ ), and Biomphalaria glabrata
(Say, 1818) (Planorbidae) $(n=24)$. Regarding the bivalves, Corbicula fluminea (O. F. Müller, 1774) and Corbicula largillierti (Philippi, 1844) (Cyrenidae) have ten studies each (Table SI).

\section{Inventory of the Piauí collections}

Regarding the collections on the Piaui state, a total of 25,168 alive mollusks were sampled in Itaim and Guaribas rivers, belonging to 11 species of Gastropoda and Bivalvia classes (Table I, Figure 4). The gastropods belong to families Planorbidae, Physidae, Thiaridae and Ampullariidae. The bivalves were represented by Cyrenidae and Sphaeriidae.

Regarding the Gastropoda species collected in the rivers, $M$. tuberculatus was the most abundant species ( $n=18,234 ; 72.45 \%)$, followed by $B$. straminea $(n=3,800 ; 15.10 \%)$, Drepanotrema schubarti (Haas, 1938) ( $n=1,233 ; 4.90 \%)$,
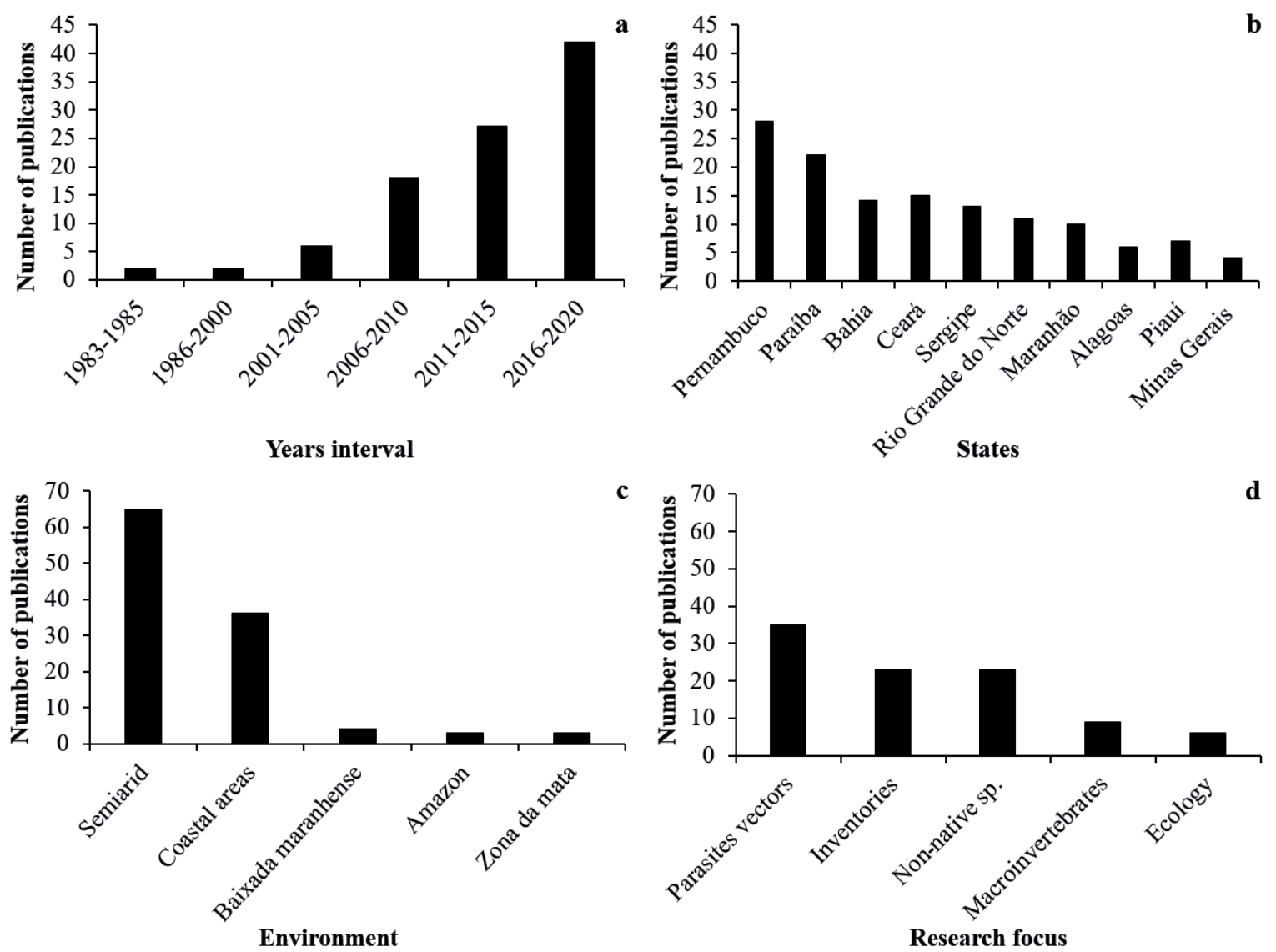

Figure 1. Distribution of studies on freshwater mollusks in the Northeast and Brazilian semiarid (a) over the years, (b) by state, (c) type of environment, and (d) focus of the research. 
Drepanotrema depressissimum (Moricand, 1839) ( $n=749 ; 2.98 \%)$, Pomacea canaliculata (Lamarck, 1822) ( $n=476 ; 1.89 \%)$, Stenophysa marmorata (Guilding, 1828) ( $n=196 ; 0.78 \%$ ), Drepanotrema lucidum (L. Pfeiffer, 1839) ( $n=126 ; 0.50 \%)$, Drepanotrema cimex (Moricand, 1839) ( $n=106$; $0.42 \%$ ) and Uncancylus concentricus (d'Orbigny, 1835) ( $n=2 ; 0.01 \%$ ) (see Table I; Figure 5). Considering Bivalvia the most abundant species was Pisidium dorbignyi Clessin, 1879 ( $n=243$; $0.97 \%)$, followed by C. fluminea $(n=3 ; 0.01 \%)$ (see Table I and Figures 4 and 5).

The Guaribas River presented the highest species richness with nine records, while the Itaim River, only five (Figure 5). Melanoides tuberculatus, B. straminea and P. canaliculata, were sampled in the two studied environments. Drepanotrema schubarti, D. depressissimum,
D. cimex, D. lucidum, S. marmorata and U. concentricus were present only in the Guaribas River, while $P$. dorbignyi and $C$. fluminea were exclusive to the Itaim River (Table I and Figure 5).

\section{Distribution status of species found in Piauí}

Concerning Gastropoda analyses results, in the Northeast, B. straminea is the species of the genus with the greatest geographic distribution, being present in all states, including in the semiarid part (Figure 5). Drepanotrema cimex and $D$. lucidum have records in eight of the nine states in the Northeast, including Piaui, and in semiarid of these states (Figure 5). Drepanotrema drepressissimum was recorded in six states in the Northeast, including Piaui, and the semiarid region of these states (Figure 5). The non-native snail $M$. tuberculatus is not registered only in

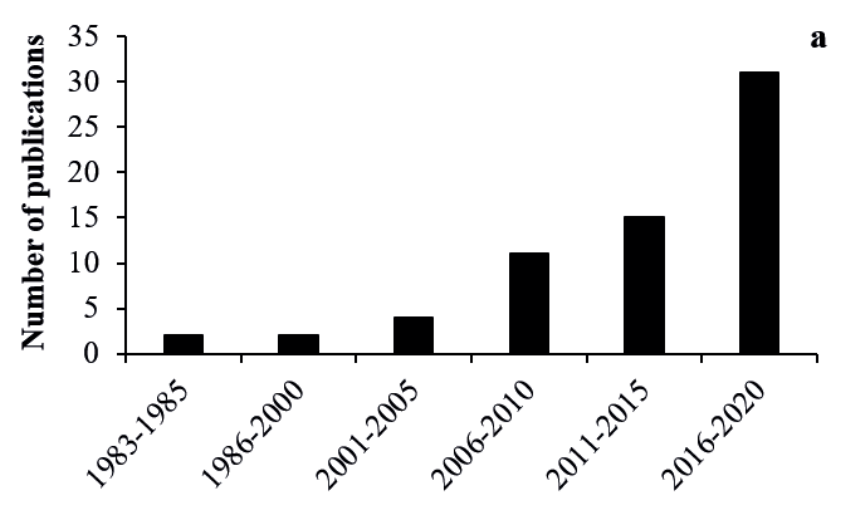

Years interval

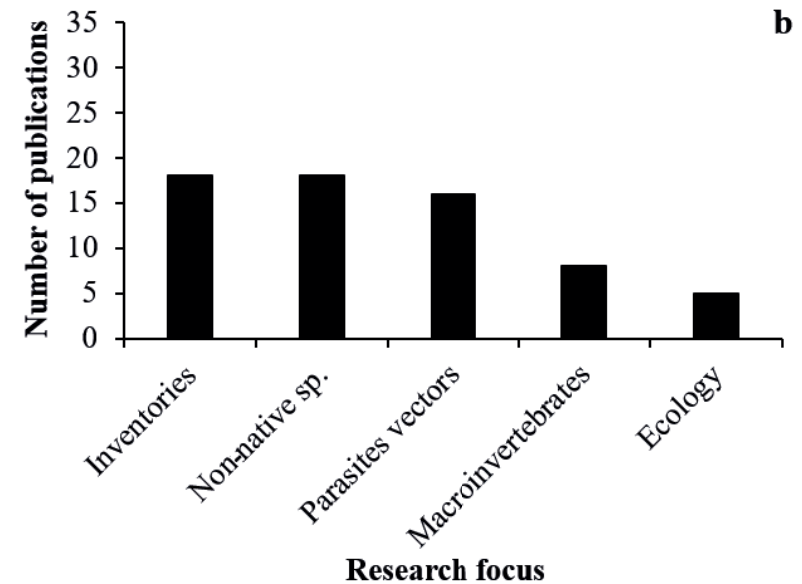

c

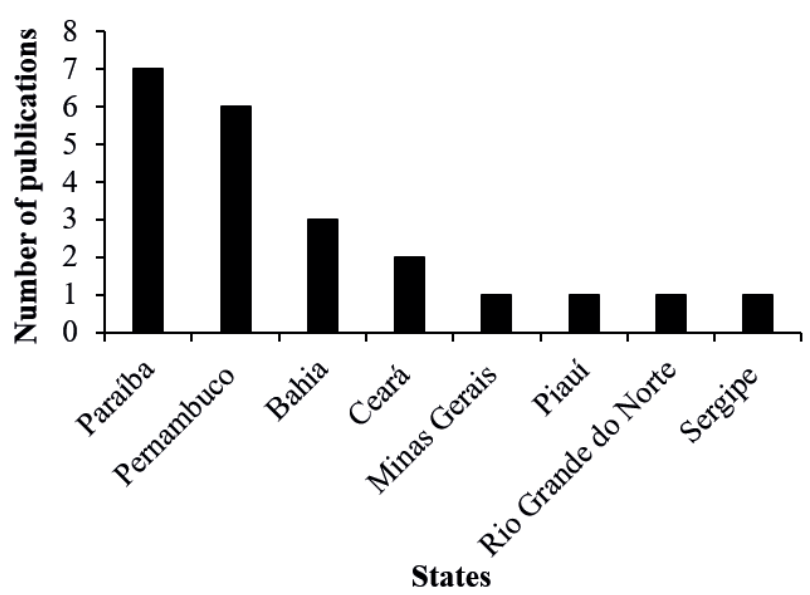

Figure 2. Distribution of studies on freshwater mollusks in the Brazilian semiarid (a) over the years, (b) focus of the research, and (c) by state. 
Maranhão state, including the semiarid of that state (Figure 5). Pomacea canaliculata has records for the Northeast only in the states of Bahia and Pernambuco and has no records for the semiarid (Figure 5). And S. marmorata had already been recorded for the states of Bahia, Ceará, Maranhão, Paraíba, Pernambuco and Rio Grande do Norte, and has no records for the semiarid (Figure 5, for further details, see the Table SI).

Regarding Bivalvia, in the Northeast, the asian clam $C$. fluminea has already been recorded in the states of Alagoas, Bahia, Paraíba, Pernambuco, Piauí, Rio Grande do Norte, and Sergipe, and in the semiarid region of these states (Figure 5). And P. dorbignyi [= Pisidium pulchellum (d'Orbigny, 1835)] has been recorded in the states of Bahia and Pernambuco, and in the semiarid region of these states (Figure 5, for further details, see the Table SI).

By analyzing Figure 5, it is possible to confirm the first record of $U$. concentricus for the Northeast and of P. canaliculata, $S$. marmorata, D. schubarti and P. dorbignyi for Piauí. Considering the 11 species sampled, $P$. canaliculata, D. schubarti and U. concentricus had their first record for the semiarid region.

\section{DISCUSSION}

Studies that aim to gather the information in the literature about a certain group in a region are extremely important for understanding the diversity and quantitative aspects related to scientific production over the years (Kopp et al. 2007). The information gathered here
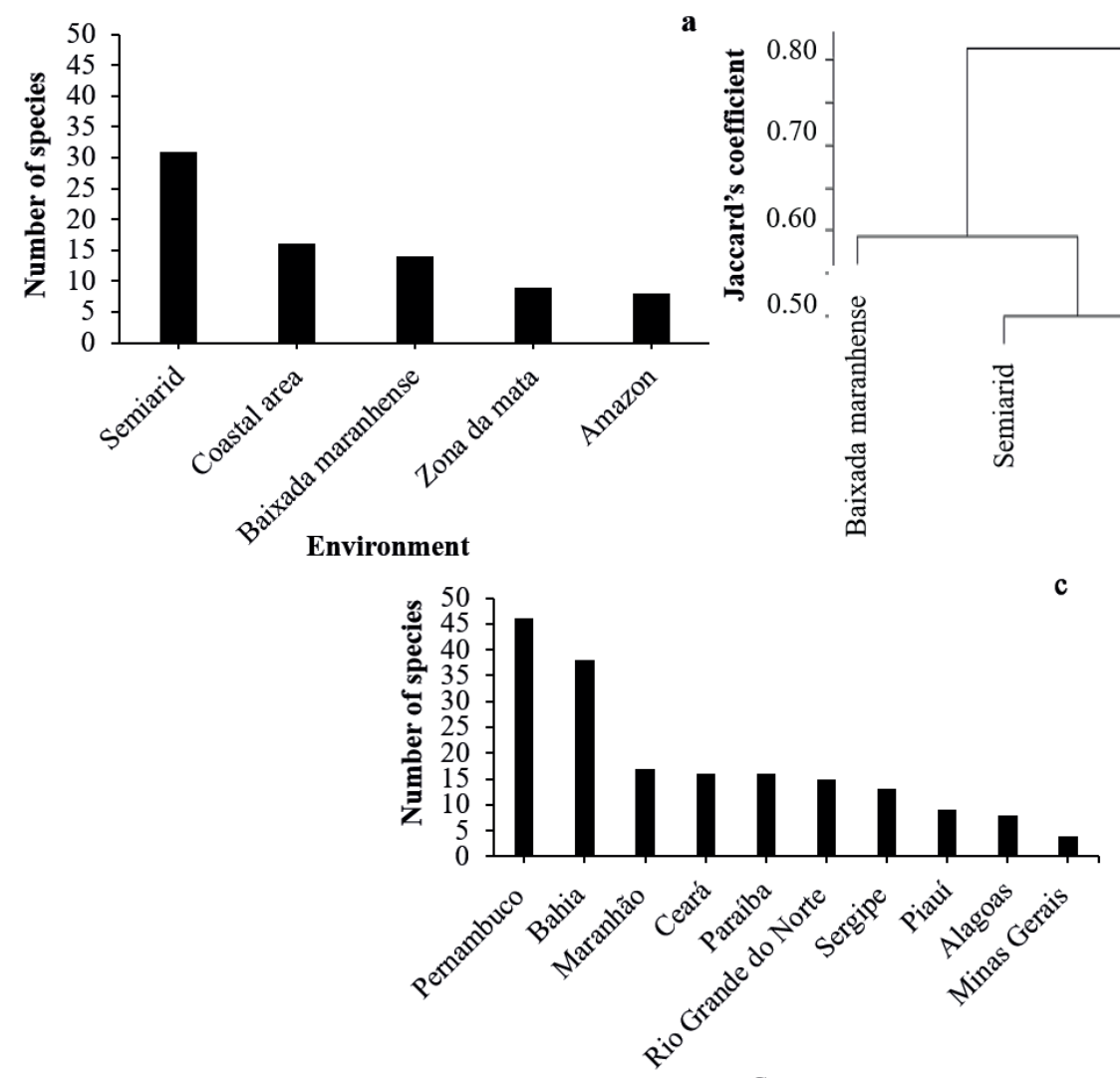

States

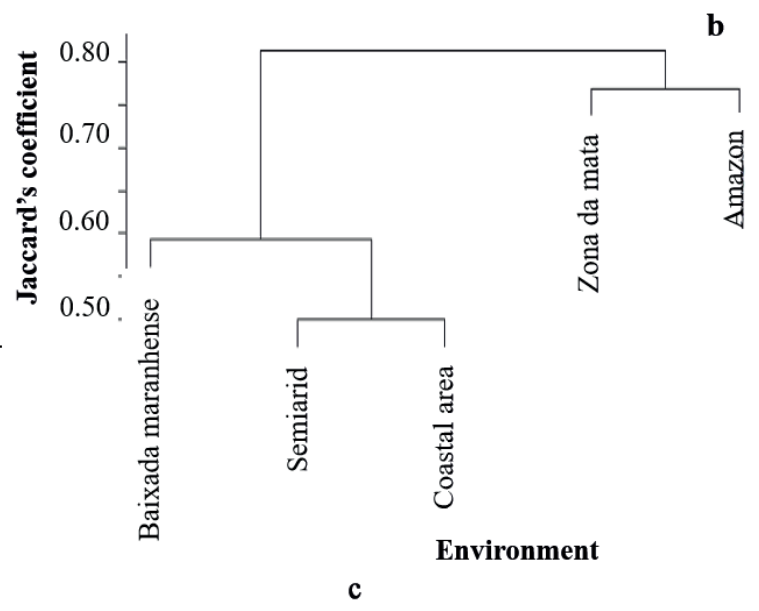

Figure 3. (a) Distribution of mollusk species by environment type; (b) Similarity dendrogram in species compositions among environments; and (c) number of molusks species by state. 


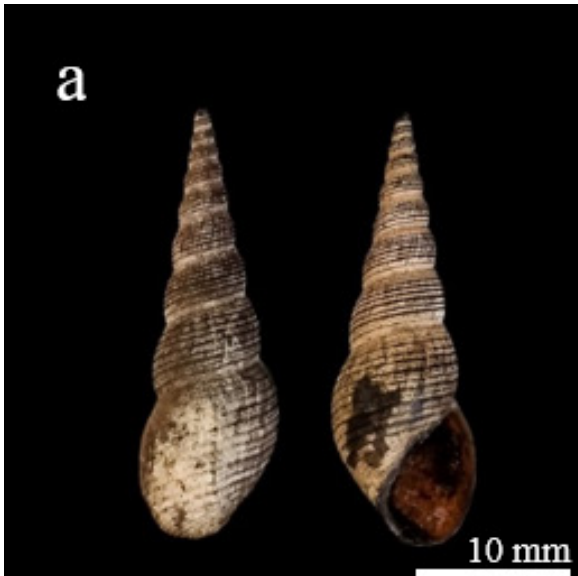

c

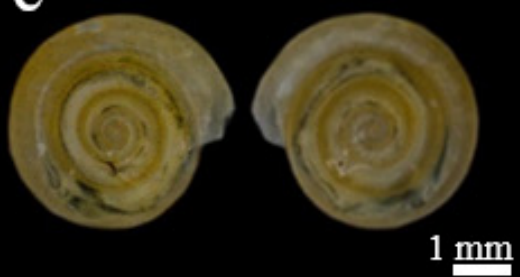

e

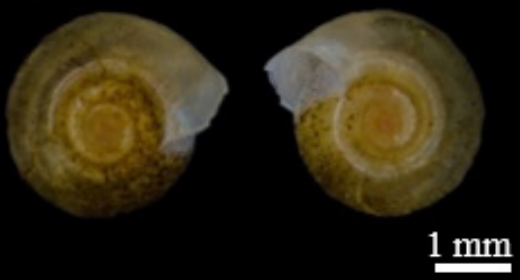

g

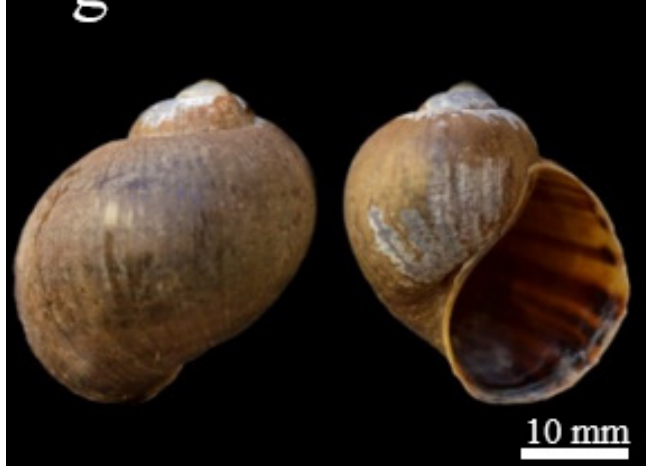

1

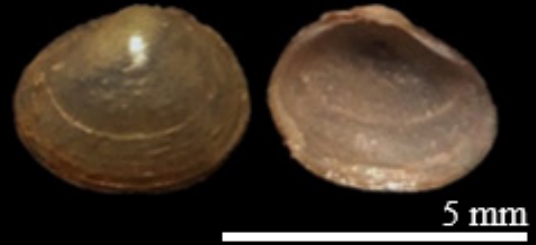

b

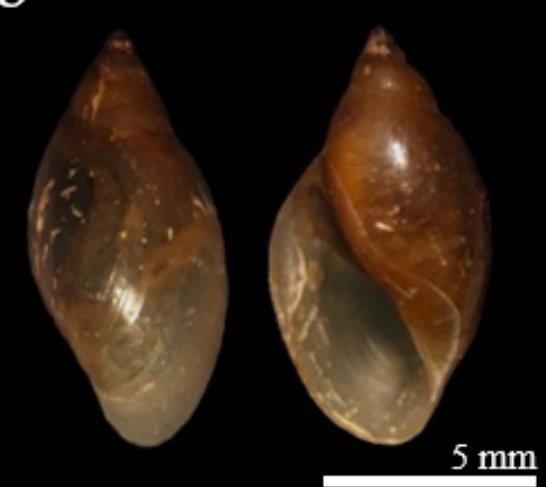

$\mathbf{1}$

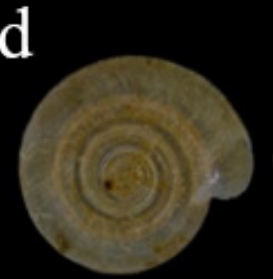

$f$
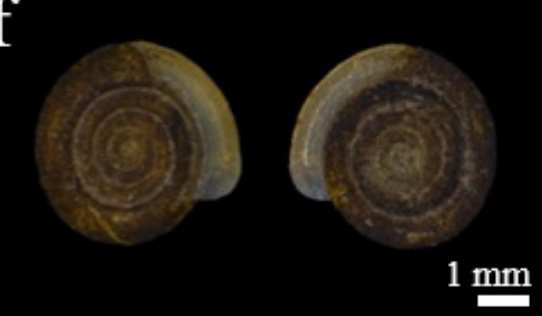

Figure 4. Mollusk species sampled in the Itaim and Guaribas rivers. (a) Melanoides tuberculatus; (b) Stenophysa marmorata; (c) Drepanotrema schubarti; (d) Drepanotrema depressissimum; (e) Drepanotrema lucidum; (f) Drepanotrema cimex; (g) Pomacea canaliculata; (h) Biomphalaria straminea; (i) Uncancylus concentricus; ( $j$ ) $1 \mathrm{~mm}$ Pisidium dorbignyi; (k) Corbicula fluminea.

h
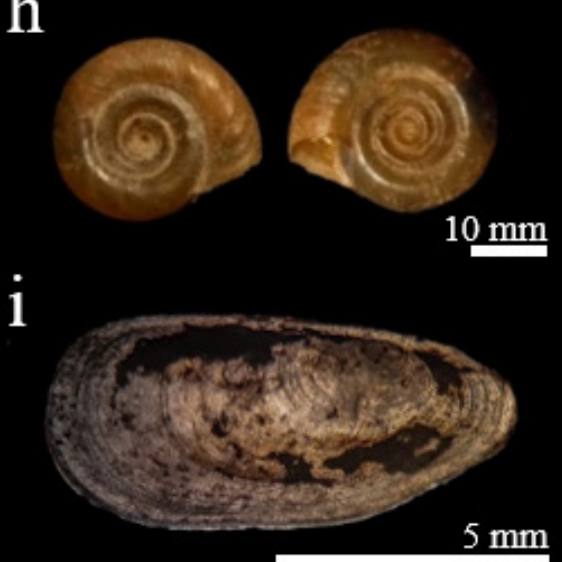

$\mathbf{K}$

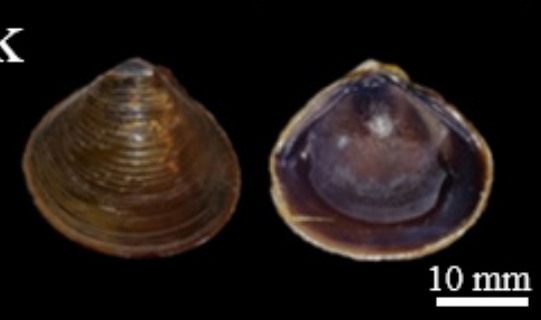




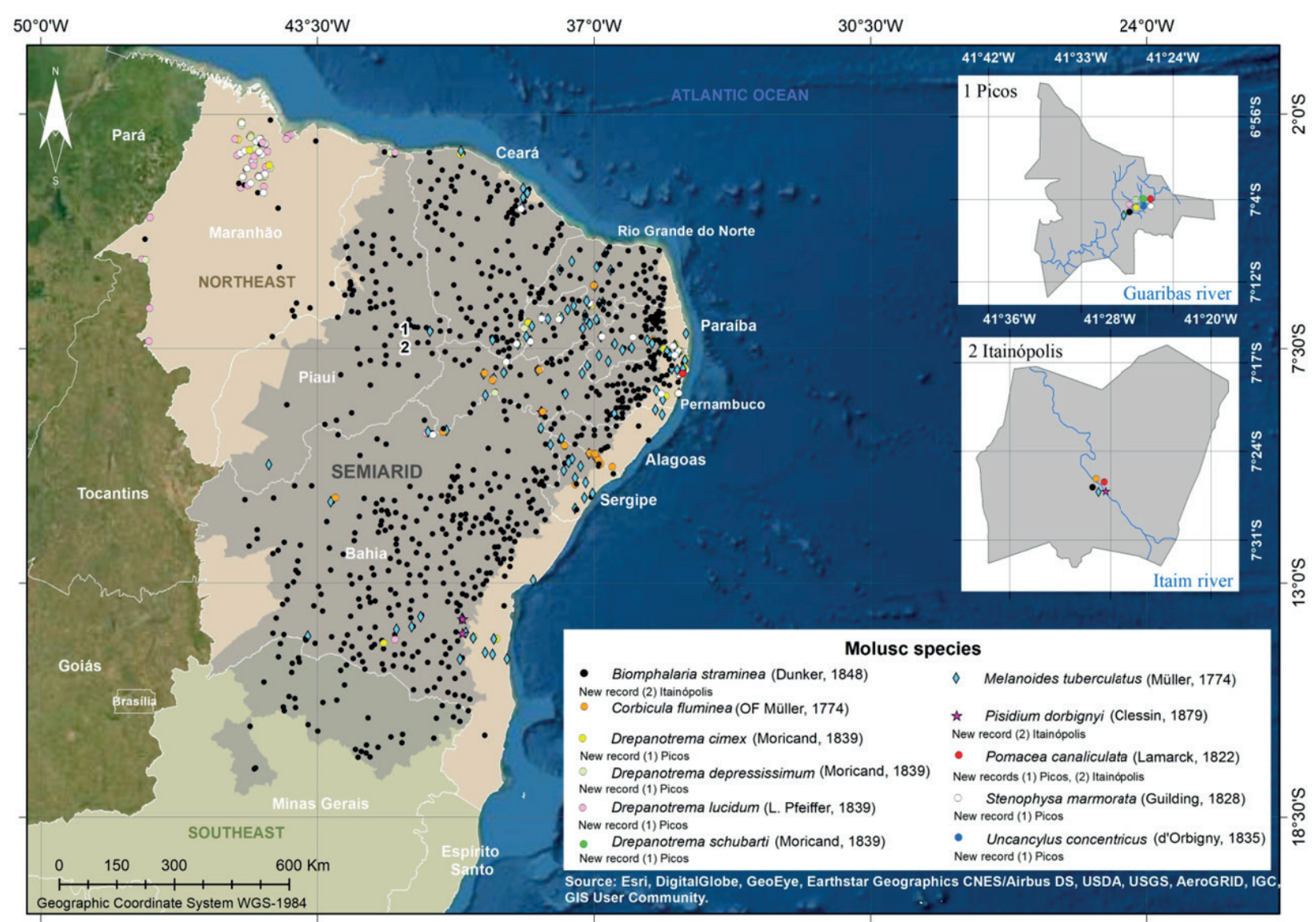

Figure 5. Geographic distribution of mollusk species sampled in the state of Piauí and its occurrence in the Brazilian semiarid region. (1) Guaribas River, municipality of Picos, Piauí, Brazil, and (2) Itaim River, municipality of Itainópolis, Piauí, Brazil.

may contribute to future research and to the species conservation and the environments they occupy, especially in a region such as the Brazilian semiarid region. Studies focusing on mollusks are found in the literature (Coelho et al. 2018, Santana et al. 2013, Miyahira et al. 2020, Leal et al. 2021), however, the present study is the first to gather and increase the information available on the fauna of limnic mollusks for the Northeast and Brazilian semiarid regions.

It is possible to verify that the number of studies on limnic mollusks has increased significantly over the years, both in the Northeast and in the semiarid region, mainly since 2006. This phenomenon is related to the expansion and interiorization of research centers in the country that started in 2003. This expansion, according to Bizerril (2020), contributed to regional development in several ways, favoring not only the academic environment but also the social one. The expressive number of studies focusing on vector species of parasites and non-native species are responses to the knowledge bottleneck problem on the diversity of mollusks in the region. Add to that, the social and environmental concern of researchers, considering the Northeast has the lowest Human Development Index (HDI) of the country (United Nations Development Program 2016) and has urgent demands in these areas (Katz 2018, Silva et al. 2019, Leal et al. 2021).

Thus, given the circumstances under which these surveys have been carried out, it is likely that the determination of the local diversity of 
mollusks is underestimated, especially if we consider that $50 \%$ of the species attributed to the Northeast region do not have the determination of the type of environment in which they occur. Therefore, there is still a hidden diversity in the semiarid region, which does not allow us to affirm that this region is characterized by having low species richness.

The severe dynamics of climatic conditions in the semiarid region require adaptive strategies from mollusks such as reduction in body size, increase in reproductive rate and physiological tolerances, development of the capacity for aestivation and dispersion among other animals for a rapid recolonization of the seasonally disturbed environment (McMahon 2002, Diáz et al. 2008, Santana et al. 2009, Work \& Mills 2013, Okumura \& Rocha 2020). Thus, the low diversity of these animals attributed to the semiarid climate may be related to the spot sampling methods that disregard the periodic local changes and particularities of the occupation and landscape of water bodies.

These effects were observed in the difference in species composition observed between the two surveyed rivers from Piauí, possibly related to the conservation status of each habitat. Although the collection points in both environments are in the urban areas, the Guaribas River presents greater evidence of anthropic changes than those observed in the Itaim River. In the Guaribas River, there is a higher deposition of solid waste and the release of untreated domestic effluents, also observed by Santos et al. (2017). According to Miranda et al. (2016), anthropic interference generates a large amount of organic matter in the riverbed, making the environment favorable to the establishment of some species of mollusks. Besides, the muddy substrate and the broadest area covered by macrophytes are relevant factors for the distribution of limnic mollusks (Santos et al. 2017, Bespalaya et al. 2020). Then, these conditions explain a greater number of species in the Guaribas River related to the Itaim River.

The Planorbidae stood out for presenting the largest number of species collected in this study. It has a wide global distribution, and, in Brazil, it is frequently found in all regions (Simone 2006, Saito et al. 2020). Among the species of Planorbidae, B. straminea stands out for adapting to almost all environmental conditions in the country, being present in most Brazilian rivers (Scholte et al. 2012, Carvalho et al. 2018). It is considered the most important species for the maintenance of the Schistosoma mansoni (Sambon, 1907) cycle in the Northeast (Scholte et al. 2012). For this reason, the distribution of $B$. straminea is the best known, with the largest number of records for both the Northeast and the semiarid regions. In the state of Piaui it has been registered in 66 municipalities (Carvalho et al. 2008, Silva et al. 2020b). Despite the existence of records of B. glabrata in the state (Paraense \& Araujo 1984, Carvalho et al. 2008), there are no reports of co-occurrence with $B$. straminea, according already been reported by Guimarães et al. (2009) for other water bodies in the semiarid. Due to the difference in the susceptibility to $S$. mansoni infection already observed between these species (Dias et al. 1987), it is relevant to study the distribution, taxonomy, and ecology of this genus across the state.

In general, species of the genus Drepanotrema are drought-tolerant, often found in temporary water bodies, which are occasionally flooded (Pointier \& David 2004, Kotzian \& Amaral 2013). Considering its short life cycle, they can quickly reestablish populations with the return of rain (Pointier \& David 2004). Also, the occurrence of macrophytes (mainly of species belonging to the families Charophyceae, Poaceae, and Pontederiaceae) (Sousa et al. 2019) may be another relevant 
factor for the maintenance of populations in the studied environment. This is justified because macrophytes provide shelter and food for Drepanotrema species (Paraense 1972, Pointier \& David 2004, Bueno-Silva \& Fischer 2005, Santos et al. 2017, Moura et al. 2019). Thus, the extreme environmental conditions associated with contrasting hydric perturbations, such as those studied, do not limit the occurrence of these species.

Drepanotrema cimex and D. lucidum successfully colonize different types of lotic and lentic environments that range from wetlands, drainage channels, reservoirs of hydroelectric plants, rivers and fish farming tanks. Data on D. schubarti are scarce throughout Brazil. This species was considered a synonym of D. lucidum by Paraense $(1975,1983)$ due to similarities in the characteristics of the shell such as globular spirals and a more rounded lip. However, Simone (2006) considered D. schubarti as a valid species. Only one study reports the occurrence of this species in the Northeast for the states of Alagoas, Ceará, Paraíba, Pernambuco and Rio Grande do Norte (Simone 2006). Therefore, our study has the first record for the state of Piaui. The $D$. schubarti distribution may be underestimated in the Northeast and semiarid regions due to the taxonomic similarities between this species and D. lucidum. Therefore, greater attention should be paid to the identification of both.

Uncancylus concentricus is usually found in rivers with low flow, but it can also colonize stagnant water, streams, lakes, or ponds (Jara 2011). Their populations are regulated by water temperature, which can affect growth and reproductive activity (Martín \& Díaz 2012). For the Northeast, there are only two records, one for Bahia and the other for Rio Grande do Norte, but these data are not confirmed (Santos et al. 2009). Thus, this is the first official record of the species in the region.
Melanoides tuberculatus has its broadest geographical distribution in Northeast Brazil, occurring in eight of the nine states (Coelho et al. 2018, Silva et al. 2019). It is a non-native and invasive species, which tolerates a wide range of environmental conditions (Cao et al. 2017, Coelho et al. 2018, Freire \& Marafon 2018) and it is easily observed in the semiarid water bodies (Callisto et al. 2005, Silva \& Barros 2011, Silva et al. 2019). In addition to having a high reproductive rate and a parthenogenetic reproduction it has the necessary conditions to withstand various environmental stress situations, such as desiccation, high temperatures and low oxygen content (Callisto et al. 2005, Silva \& Barros 2011, Weir \& Salice 2011). The presence of M. tuberculatus with high population densities has been associated with a decrease in the diversity and abundance of native species and even local extinctions in several regions of Brazil (Fernandez et al. 2001, Guimarães et al. 2001, Giovanelli et al. 2003, Almeida et al. 2018, Silva et al. 2019). In addition to the biological aspects inherent in the $M$. tuberculatus mentioned above, environmental characteristics such as warmer temperatures, slow or still waters and shallow margins, also observed in the studied rivers, were identified as important factors for the establishment of this invasive species (Duggan 2002, Kock \& Wolmarans 2009). Thus, permanent monitoring is necessary to predict and avoid the downside effects on the local fauna.

Stenophys a marmorata is considered a pioneer species, capable of inhabiting temporary bodies of water, exploring favorable conditions and quickly re-establishing populations (Núñez 2011). According to Fernandez et al. (2010), this species is recorded in lotic and lentic water bodies and is frequently associated with polluted environments or with some degree of anthropization (dams, reservoirs, fish farming 
tank and streams). These factors justify its occurrence in the Guaribas River. Although it has already been registered in six states in the Northeast, including the semiarid, this is the first record of S. marmorata for Piauí. This species deserves attention, as it is vulnerable (Brasil 2018).

Pomacea canaliculata usually inhabits shallow, slow, or stagnant waters, including water bodies that often dry out over a year (Havel et al. 2014, Hayes et al. 2015). It is a species considered adapted to the conditions imposed by drought because it has an amphibious habit and estivation ability (Glasheen et al. 2017). Despite its occurrence, this species is registered in only two states of the Northeast, and the environmental changes resulting from the scarcity of rainfall in this region does not limit its occurrence in the semiarid. Thus, this study brings the first record of this species to the state of Piaui and the Brazilian semiarid region. This record expands its known distribution in the Northeast, reinforcing the importance of surveying the mollusk fauna in this region.

Unlike pulmonary gastropods, Sphaeriidae bivalves are not well adapted to seasonally unfavorable environmental conditions, preferring more stable hydroperiods (Kotzian \& Amaral 2013). Therefore, the conditions imposed by the drought in the semiarid can hinder their establishment. Different from gastropods, these bivalves commonly colonize deeper places with fine sediments and need more dissolved oxygen (Kotzian \& Amaral 2013). This is the first record of $P$. dorbignyi to the state of Piaui. It draws attention to the need for studies to understand what mechanisms are used to compensate for the limitations imposed by drought, and how it manages to reestablish its populations with the return of rains in the semiarid.

Unlike P. dorbignyi, the asian clam Corbicula fluminea is more resistant and tolerates a wide range of environmental conditions (Coelho et al. 2018, Cao et al. 2017). Its distribution is expanding in the Brazilian territory and found in all regions (Freire \& Marafon 2018, Darrigran et al. 2020, Leal et al. 2021). Its occurrence in the Northeast and semiarid region is well documented and indicates a constant expansion rate (Leal et al. 2021, Darrigran et al. 2020). This species is generally observed in high population densities, it can change the dynamics of the environments in which they live and affect the fauna of other species of limnic mollusks (Ilarri \& Sousa 2012, Santana et al. 2013, Gomes et al. 2016, Leal et al. 2021).

The conditions found in the surveyed area, such as high-water temperature, shallow bed, and sandy substrate, are ideal for the occurrence of Corbicula species (Leal et al. 2021). Although the collection methodology used in this study is not the most suitable for sampling these bivalves, the low number of individuals collected in the Itaim river suggests an event of recent introduction, since, in the two years of collection, C. fluminea was sampled only during the last three months. This information reinforces the need for studies aimed at monitoring this species.

As for the low diversity of bivalves observed in this study, we draw attention to the choice of appropriate methods for capture as they are important for determining the diversity of these animals according to already highlighted by Pereira et al. (2012).

The five new records of limnic mollusks presented in this work correspond to $7 \%$ of the current knowledge about the diversity of these animals in the Northeast region. For the semiarid, the unprecedented results take on even greater relevance, reaching $13 \%$ of the number of species recognized for this location. Considering only two years of data sampling, the promising character of the monitoring of malacofauna in the Piaui semiarid region is evident. Two aspects draw attention to the need for constant monitoring of the malacofauna and studies on the biology and ecology of this group. First, the occurrence of $B$. straminea considered 
a risk factor for the onset of schistosomiasis and the presence of two non-native species. The monitoring is relevant to predict whether, over the years, there will be resettlement of the disease and native species may be affected.

\section{Acknowledgments}

The authors are grateful to the Coordenação de Aperfeiçoamento de Pessoal de Nivel Superior - (CAPES) and to the Conselho Nacional de Desenvolvimento Científico e Tecnológico - CNPq (421582 / 2018-9) for providing financial support, to Instituto Federal Piauí IFPI (PROAGRUPAR-INFRA 154/2019) for the logistic and financial support, to the curation team from the Mollusk Collection of Museu de Zoologia da Universidade de São Paulo, São Paulo, Brazil (MZUSP) for the identification of specimens, and to the editor and anonymous reviewers for their suggestions to our manuscript.

\section{REFERENCES}

ABÍLIO FJP, FONSECA-GESSNER AA, LEITE RL \& RUFFO TLM. 2006. Gastrópodes e outros invertebrados do sedimento e associados à macrófita Eichhornia crassipes de um açude hipertrófico do semi-árido paraibano. Rev Biol Ciênc Terra Supl (1): 165-178.

ABÍLIO FJP, RUFFO TLM, SOUZA AHFF, FLORENTINO HS, OLIVEIRA-JUNIOR ET, MEIRELES BN \& SANTANA ACD. 2007. Macroinvertebrados bentônicos como bioindicadores de qualidade ambiental de corpos aquáticos da caatinga. Oecol Bras 11 (3): 397-409.

ALMEIDA PRS, NASCIMENTO-FILHO SL \& VIANA GFS. 2018. Effects of invasive species snails in continental aquatic bodies of Pernambucano semiarid. Acta Limnol Bras 30(0): 1-10.

BARBOSA JEL, MEDEIROS ESF, BRASIL J, CORDEIRO RS, CRISPIM MCB \& SILVA GHG. 2012. Aquatic systems in semiarid Brazil: limnology and management. Acta Limnol Bras 24(1): 103-118.

BESPALAYA YV, AKSENOVA OV, SOKOLOVA SE, SHEVCHENKO AR, TOMILOVA AA \& ZUBRII NA. 2020. Biodiversity and distributions of freshwater mollusks in relation to chemical and physical factors in the thermokarst lakes of the Gydan Peninsula, Russia. Hydrobiologia 848(2): 3031-3044.

BIZERRIL MXA. 2020. The process of expansion and interiorization of brazilian Federal Universities and their developments. Rev Tempos Espaços Educ 13(32): e-13456.

BRASIL. 2005. Recursos Hídricos do Estado do Piauí. Atlas do Abastecimento de Água do Estado do Piauí. Brasília: Agência Nacional de Águas/Semar. Available in: http://
www.pi.gov.br/download/CANIN.pdf. Accessed 10 Jul 2020.

BRASIL. 2017. Nova delimitação Semiárido, Superintendência do Desenvolvimento do Nordeste (SUDENE). Available in: http://antigo.sudene.gov.br/ delimitacao-do-semiarido. Accessed 23 Mai 2021.

BRASIL. 2018. Instituto Chico Mendes De Conservação Da Biodiversidade (ICMBio). 2018. Livro Vermelho da Fauna Brasileira Ameaçada de Extinção: Volume I. ICMBio, Brasilia, 492 p. Available in: https://www.icmbio.gov.br/ portal/component/content/article/10187. Accessed 10 Jul 2020.

BUENO-SILVA M \& FISCHER ML. 2005. Dinâmica populacional de Drepanotrema cimex (Moricand, 1839) (Mollusca: Basommatophora: Planorbidae) no Parque Barigüi, Curitiba, Paraná, Brasil. Biotemas 18(2): 129-141.

CALLISTO M, GOULART M, BARBOSA FAR \& ROCHA O. 2005. Biodiversity assessment of benthic macroinvertebrates along a reservoir cascade in the lower São Francisco River (Northeastern Brazil). Braz J Biol 65(2): 229-240.

CAO L, DAMBORENEA C, PENCHASZADEH PE \& DARRIGRAN G. 2017. Gonadal cycle of Corbicula fluminea (Bivalvia: Corbiculidae) in Pampean streams (Southern Neotropical Region). PLOS ONE 12(10): 1-16.

CARVALHO O, AMARAL R, DUTRA L, SCHOLTE R \& GERRA M. 2008. Distribuição Espacial de Biomphalaria glabrata, $B$. straminea e $B$. tenagophila, Hospedeiros Intermediários do Schistosoma mansoni no Brasil. In: CARVALHO OS et al. (Eds), Schistosoma mansoni e Esquistossomose: uma visão multidisciplinar, Editora Fiocruz, Rio de Janeiro, p. 393-418.

CARVALHO OS ET AL. 2018. Distribuição geográfica dos hospedeiros intermediários do Schistosoma mansoni nos estados do Paraná, Minas Gerais, Bahia, Pernambuco e Rio Grande do Norte, 2012-2014. Epidemiol Serv Saude 27(3): 1-9.

COELHO PN, FERNANDEZ MA, CESAR DAS, RUOCCO AMC \& HENRY R. 2018. Updated distribution and range expansion of the gastropod invader Melanoides tuberculata (Müller, 1774) in Brazilian waters. Bioinvasions Rec 7(4): 405-409.

DARRIGRAN G ET AL. 2020. Non-native mollusks throughout South America: emergent patterns in an understudied continent. Biol Invasions 22(3): 853-871.

DIAS LCS, UETA MT \& GUARALDP AMP. 1987. Susceptibilidade de Biomphalaria glabrata, B. straminea e B. tenagophila a diferentes cepas de Schistosoma mansoni. Rev Inst Med trop 29(4): 204-212.

DÍAZ AM, ALONSO MLS \& GUTIÉRREZ MRVA. 2008. Biological traits of stream macroinvertebrates from a semiarid catchment: patterns along complex environmental gradientes. Freshw Biol (53): 1-21. 
DUGGAN IC. 2002. First record of a wild population of the tropical snail Melanoides tuberculata in New Zealand natural waters. N Z J Mar Freshwater Res 36: 825-829.

FERNANDEZ MA, THIENGO SC, BEZERRA FSM \& ALENCAR LMS. 2010. Current distribution of the exotic freshwater snail Helisoma duryi (Gastropoda: Planorbidae) in Brazil. The Nautilus 124(1): 44-50.

FERNANDEZ MA, THIENGO SC \& BOAVENTURA MF. 2001. Freshwater snails of the Campus of Manguinhos, Oswaldo Cruz Foundation, Rio de Janeiro, RJ. Rev Soc Bras Med Trop 34(3): 279-282.

FREIRE CG \& MARAFON AT. 2018. Espécies de moluscos invasores nos ecossistemas aquáticos brasileiros e seu impacto no meio ambiente. InterfacEHS 13(1): 2-16.

GIOVANELLI A, VIEIRA MV \& SILVA CLPAC. 2003. Apparent Competition Through Facilitation between Melanoides tuberculata and Biomphalaria glabrata and the Control of Schistosomiasis. Mem Inst Oswaldo Cruz 98(3): 429-431.

GLASHEEN PM, CALVO C, MEERHOFF M, HAYES KA \& BURKS RL. 2017. Survival, recovery, and reproduction of apple snails (Pomacea spp.) following exposure to drought conditions. Freshw Sci 36(2): 316-324.

GOMES ECS, MESQUITA MCS, REHN VNC, CORREIA-NASCIMENTO WR, LOYO R \& BARBOSA CS. 2016. Transmissão urbana da esquistossomose: Novo cenário epidemiológico na Zona da Mata de Pernambuco. Rev bras epidemiol 19(4): 822-834.

GUIMARÃES CT, SOUZA CP \& SOARES DM. 2001. Possible Competitive Displacement of Planorbids by Melanoides tuberculata in Minas Gerais, Brazil. Mem Inst Oswaldo Cruz 96: 173-176.

GUIMARÃES RJPS ET AL. 2009. Spatial distribution of Biomphalaria mollusks at São Francisco River Basin, Minas Gerais, Brazil, using geostatistical procedures. Acta Trop 109(3): 181-186.

HAVEL JE, BRUCKERHOFF L, FUNKHOUSER MA \& GEMBERLING A. 2014. Resistance to desiccation in aquatic invasive snails and implications for their overland dispersal. Hydrobiologia 741(1): 89-100.

HAY SE, JENKINS KM \& KINGSFORD RT. 2018. Diverse invertebrate fauna using dry sediment as a refuge in semiarid and temperate Australian rivers. Hydrobiologia 806: 95-109.

HAYES KA ET AL. 2015. Insights from an integrated view of the biology of apple snails (Caenogastropoda: Ampullariidae). Malacologia 58(1-2): 245-302.

ILARRI M \& SOUSA R. 2012. Corbicula fluminea Müller (Asian clam). In: FRANCIS R et al. (Eds), A Handbook of Global Freshwater Invasive Species, Earthscan, London, p. 173-183.
JARA CF. 2011. Uncancylus concentricus (d’orbigny, 1835): antecedentes de la espécie. Amici Molluscarum 19: 41-43.

KATZ N. 2018. Inquérito Nacional de Prevalência da Esquistossomose mansoni e Geo-helmintoses, Belo Horizonte: Fiocruz, 76 p.

KOCK KN \& WOLMARANS CT. 2009. Distribution and habitats of Melanoides tuberculata (Müller, 1774) and M. victoriae (Dohrn, 1865) (Mollusca: Prosobranchia: Thiaridae) in South Africa. Water SA 35(5): 713-720.

KOPP K, ANTONIOSI-FILHO NR, ALVES MIR \& BASTOS RP. 2007. Publicações Sobre Efeitos de Pesticidas em Anfíbios no Período de 1980 a 2007. Multiciência 8: 173-186.

KOTZIAN CB \& AMARAL AMB. 2013. Diversity and distribution of mollusks along the Contas River in a tropical semiarid region (Caatinga), Northeastern Brazil. Biota Neotropica 13(4): 299-314.

LEAL MF, SIMONE LRL, LACERDA ACF, SILVA EL \& PINHEIRO TG. 2021. Current distribution of the invasive mollusk Corbicula fluminea (O.F. Müller, 1774) (Bivalvia, Cyrenidae) in Brazil, including a new record from the state of Piauí. Check List 17(1): 151-157.

MAGALHÃES PS, SIMÕES NR \& SONODA SL. 2016. Limnologia de rios intermitentes: a bacia hidrográfica do rio Jequiezinho como estudo de caso. In: MORAES MEB \& LORANDI R (Eds), Métodos e técnicas de pesquisa em bacias hidrográficas, Editora Editus, Ithéus, Brasil, p. 163-181.

MALTCHICK L \& FLORÍN MF. 2002. Perspectives of hydrologycal disturbance as the driving force of the Brazilian semiarid ecosystem. Acta Limnol Bras 14(3): 35-41.

MALTCHIK L \& MEDEIROS ESF. 2006. Conservation importance of semiarid streams in north-eastern Brazil: implications of hydrological disturbance and species diversity. Aquatic Conserv: Mar Freshw Ecosyst 16: 665-677.

MANAYE A, NEGASH M \& ALEBACHEW M. 2019. Effect of degraded land rehabilitation on carbon stocks and biodiversity in semiarid region of Northern Ethiopia. Forest Sci Technol 15(2): 70-79.

MARTÍN MS \& DÍAZ AC. 2012. Population structure of Uncancylus concentricus (d'Orbigny, 1835) (Ancylidae, Pulmonata, Basommatophora) in the Multiple Use Reserve Martín García Island, Upper Río de la Plata, Argentina. Braz J Biol 72(1): 65-70.

MCMAHON RF. 2002. Evolutionary and physiological adaptations of aquatic invasive animals: $r$ selection versus resistance. Can J Fish Aquat Sci 59: 1235-1244.

MIRANDA GS, RODRIGUES JGM, LIRA MGS, NOGUEIRA RA, GOMES GCC, MIRANDA BS, ARAÚJO A \& SILVA-SOUZA N. 2016. MoluscoS límnicos como hospedeiros de trematódeos digenéticos de uma região metropolitana da ilha do Maranhão, Brasil. Scientia Plena 12(9): 1-11. 
MIYAHIRA IC, PEREIRA LS \& SANTOS LM. 2020. Non-native freshwater molluscs in the Neotropics: what can be learned from Brazilian reservoirs? Aquat Invasions 15(3): 455-472.

MOURA F, SOUSA W, LEITE C, PACHECO A, MARCIA M, PINHEIRO T, SILVA E \& ABREU M. 2019. Diferença sazonal da biomassa de macrófitas em um rio no semiárido do Piauí - Brasil. In 70 Congresso Nacional de Botânica (Rocha L.L., coord.). Sociedade Botânica do Brasil, Maceió, p. 377378. Available in: https://70cnbot.botanica.org.br/anais/. Accessed 23 Mai 2021. (Unpublished).

NÚÑEZ V. 2011. Fecundity and survival advantages of an exotic gastropod compared to a native species. Amer Malac Bull 29(1-2): 95-103.

OKSANEN JF ET AL. 2020. vegan: Community Ecology Package. R package version 2.5-7. Available in: https:// cran.r-project.org/web/packages/vegan/index.html. Accessed 23 May 2021

OKUMURA DT \& ROCHA O. 2020. Life history traits of the exotic freshwater snail Melanoides tuberculata Müller, 1774 (Gastropoda, Thiaridae), and its sensitivity to common stressors in freshwaters. Acta Limnol Bras 32(e19): 1-10

PARAENSE WL. 1972. Fauna planorbídica do Brasil. In: LACAZ CS et al. (Eds), Introdução à geografia médica do Brasil. Editora da Universidade de São Paulo, São Paulo, Brasil, p. 213-239.

PARAENSE WL. 1975. Estado atual da sistemática dos planorídeos brasileiros. Arq Mus Nac 55: 105-128.

PARAENSE WL. 1983. A survey of planorbid Molluscs in the amazonian region of Brazil. Mem Inst Oswaldo Cruz 78(3): 343-361.

PARAENSE WL. 2003. A Bird's Eye Survey of Central American Planorbid Molluscs. Mem Inst Oswaldo Cruz 98(1): 51-67.

PARAENSE WL \& ARAUJO MV. 1984. Biomphalaria glabrata no estado do Piauí. Mem Inst Oswaldo Cruz 79(3): 385-387.

PEREIRA D, ARRUDA JO, BERGONCI PEA, OLIVEIRA AS, POSTIGLIONE R \& MANSUR MCD. 2012. In: MANSUR MCD, SANTOS CP, PEREIRA D, PAZ ICP, ZURITA MLL, RODRIGUEZ MTR, NEHRKE MV \& BERGONCI PEA (Eds), Moluscos límnicos invasores no Brasil: biologia, prevenção e controle. Redes Editora, Porto Alegre, Brazil, p. 155-184.

POINTIER JP \& DAVID P. 2004. Biological control of Biomphalaria glabrata, the intermediate host of schistosomes, by Marisa cornuarietis in ponds of Guadeloupe: Long-term impact on the local snail fauna and aquatic flora. Biol Control 29(1): 81-89.

R CORE TEAM. 2021. R: A language and environment for statistical computing. R Foundation for Statistical Computing, Vienna, Austria. Available in: https://www.rproject.org/. Accessed 23 May 2021.
RANDKLEV CR ET AL. 2018. A semiarid river in distress: Contributing factors and recovery solutions for three imperiled freshwater mussels (Family Unionidae) endemic to the Rio Grande basin in North America. Sci Total Environ 631-632: 733-744.

ROCHA LG, MEDEIROS ESF \& ANDRADE HTA. 2012. Influence of flow variability on macroinvertebrate assemblages in an intermittent stream of semiarid Brazil. J Arid Environ 85: 33-40.

SAITO T, CHIBA S \& FUKUDA H. 2020. Type materials of the species of the Planorbidae (Mollusca, Gastropoda, Hygrophila) described by Shuichi Mori. Molluscan Res 40(2): 169-182

SANTANA ACD, SOUZA AHFF, RIBEIRO LL \& ABÍLIO FJP. 2009. Macroinvertebrados associados à macrófita aquática Najas marina L. do riacho Avelós, na região semi-árida do Brasil. Rev Biol Ciênc Terra 9(2): 1-16.

SANTANA DO, SILVA MJM, BOCCHIGLIERI A, PANTALEÃO SM, FARIA RG, SOUZA BG, ROCHA SM \& LIMA LFO. 2013. Mollusca, Bivalvia, Corbiculidae, Corbicula fluminea (Müller, 1774): First record for the Caatinga biome, northeastern Brazil. Check List 9(5): 1072-1074.

SANTOS MRB, ABREU MC, PERON AP \& DEUS MSM. 2017. Macrófitas aquáticas de um rio temporário no semiárido nordestino. Multitemas 22(52): 53-66.

SANTOS SB, LACERDA LEM \& MIYAHIRA IC. 2009. UncancyluS concentricus (Mollusca, Gastropoda, Ancylidae): New occurrence in state of Rio de Janeiro, Brazil. Check List 4(9): 32-46.

SCHOLTE RGC, CARVALHO OS, MALONE JB, UTZINGER J \& VOUNATSOU P. 2012. Spatial distribution of Biomphalaria spp., the intermediate host snails of Schistosoma mansoni, in Brazil. Geospatial Health 6(3): 95-101.

SILVA CO, RANGEL-JUNIOR A, PERBICHE-NEVES G, PINHEIRO AP \& LACERDA SR. 2020a. Low zooplankton richness indicating adverse drought and eutrophication conditions in a reservoir in northeastern Brazil. Iheringia Sér Zool 111(e2020009): 1-7.

SILVA EC \& BARROS F. 2011. Macrofauna bentônica introduzida no Brasil: Lista de espécies marinhas e dulcícolas e distribuição atual. Oecol Aust 15(2): 326-344.

SILVA EL, LEAL MF, SANTOS O, ROCHA AJ, PACHECO ACL \& PINHEIRO TG. 2019. New records of the invasive mollusk Melanoides tuberculata (Müller, 1774) (Gastropoda, Thiaridae) in the Brazilian Northeast. Check List 15(3): 479-483.

SILVA EL ET AL. 2020b. Freshwater mollusks from three reservoirs of Piaui, northeastern Brazil. Biota Neotrop 20(1): 1-8.

SIMONE LRL. 2006. Land and Freshwater Molluscs of Brazil, FAPESP, São Paulo, 340 p. 
SOUSA WGM, SILVA EL, PACHECO ACL, PINHEIRO RG \& ABREU MC. 2019. Riqueza e distribuição de macrófitas aquáticas no Rio Guaribas, Picos, Piauí. Bol Lab Hidrobiol 29(2): 1-13.

UNITED NATIONS DEVELOPMENT PROGRAM (PNUD). 2016. Desenvolvimento humano nas macrorregiões brasileiras: 2016. PNUD, IPEA, FJP, Brasília. Available in: file:/// D:/ Downloads/undp-br-macrorregioesbrasileiras-2016.pdf. Accessed 18 jun 2021.

VIDAL-ABARCA MR, SUÁREZ ML \& RAMÍREZ-DÍAZ L. 1992. ECology of spanish semiarid streams. Limnetica 8: 151-160.

WEIR SM \& SALICE CJ. 2011. Managing the risk of invasive species: how well do functional traits determine invasion strategy and success? Integr Environ Assess Manage 7: 299-300.

WORK K \& MILLS C. 2013. Rapid population growth countered high mortality in a demographic study of the invasive snail, Melanoides tuberculata (Müller, 1774), in Florida. Aquatic Invasions 8(4): 417-425.

ZANELLA ME. 2014. Considerações sobre o clima e os recursos hídricos do semiárido nordestino. Cad Prudentino Geogr 36: 126-142.

\section{SUPPLEMENTARY MATERIAL}

\section{Table SI}

\section{How to cite}

LEAL MF, SIMONE LRL, CASTRO ES, DOS SANTOS O, DA SILVA ARV, DANTAS KKS, DE SOUSA JH, DA SILVA EL, PINHEIRO TG \& LACERDA ACF. 2021. Malacofauna of lotic environments in the Northeast and Brazilian semiarid region: current knowledge and new records. An Acad Bras Cienc 93: e20210140. DOI 10.1590/0001-3765202120210140.

Manuscript received on February 18, 2021;

accepted for publication on July 4, 2021

\section{MANUELLA F. LEAL}

https://orcid.org/0000-0002-5139-8616

LUIZ RICARDO L. SIMONE ${ }^{2}$

https://orcid.org/0000-0002-1397-9823

\section{EMERSON S. CASTRO}

https://orcid.org/0000-0002-6641-720X

\section{ORIANNA DOS SANTOS 4}

https://orcid.org/0000-0002-8099-664X

ANTÔNIA R.V. DA SILVA ${ }^{3}$

https://orcid.org/0000-0001-6409-3873

\section{KARINA K.S. DANTAS}

https://orcid.org/0000-0003-3976-1563

\section{JOÃO H. DE SOUSA ${ }^{3}$}

https://orcid.org/0000-0002-2886-1246

\section{EDSON L. DA SILVA}

https://orcid.org/0000-0002-4442-5137

TAMARIS G. PINHEIRO 3

https://orcid.org/0000-0001-7246-2691

ANA CAROLINA F. LACERDA ${ }^{1}$

https://orcid.org/0000-0001-9014-9105

${ }^{1}$ Programa de Pós-Graduação em Ciências Biológicas (Zoologia), Universidade Federal da Paraíba, Departamento de Sistemática e Ecologia, Centro de Ciências Exatas e da Natureza, Cidade Universitária, s/n, Campus I, Castelo Branco, 58059-900 João Pessoa, PB, Brazil ${ }^{2}$ Universidade de São Paulo, Museu de Zoologia, Avenida Nazaré, 481, Ipiranga, 04263-000 São Paulo, SP, Brazil

${ }^{3}$ Universidade Federal do Piauí, campus Senador Helvídio Nunes de Barros, Rua Cícero Duarte, 905, Junco, 64607-670 Picos, PI, Brazil

${ }^{4}$ Programa de Pós-Graduação em Biodiversidade e Conservação, Universidade Federal do Piauí, campus Amílcar Ferreira Sobral, BR-343, Meladão, 64808-605 Floriano, PI, Brazil ${ }^{5}$ Instituto Federal do Piauí, campus Picos, Avenida Pedro Marques de Medeiros, s/n, Pantanal, 64606-115 Picos, PI, Brazil

\section{Correspondence to: Manuella Feitosa Leal \\ E-mail:manuellafeitosa94@gmail.com}

\section{Author contributions}

MFL was responsible for the sample collection in the Itaim and Guaribas Rivers, data analysis, and manuscript elaboration. LRLS was responsible for the sample identification process and manuscript revision. OS, ARVS, KKSD and JHS contributed to data collection on the Guaribas River. ESC contributed to data collection on the Itaim River and to the elaboration of figures. ELS and TGP coordinated the research and reviewed the manuscript. ACFL coordinated data analysis and manuscript elaboration.

\section{(cc) BY}

